\title{
NAHDLATUL ULAMA, EDUCATION, AND DA'WAH: TUAN MUKHTAR MUDA NASUTION'S CONTRIBUTION IN SOUTH TAPANULI
}

\author{
Muallim Lubis ${ }^{1}$ \\ ${ }^{1}$ Institut Agama Islam Negeri Bukittinggi, Indonesia
cc) (i) (2) of the Creative Commons Attribution-ShareAlike 4.0 International License (CC-BY-SA) license (https://creativecommons.org/licenses/by-sa/4.0/) \\ (C)2021 by the authors. Submitted for possible open access publication under the terms and conditions \\ doi DOI: $\underline{\text { http://dx.doi.org/10.30983/fuaduna.v5i2.4585 }}$
}

\begin{abstract}
This article aims to analyze the contribution of Tuan Mukhtar Muda Nasution to the Nahdlatul Ulama (NU) organization, education, and da'wah, especially in the South Tapanuli region, North Sumatra. In the midst of Tuan Mukhtar's achievement, researchers have not mentioned much about his contribution. He is also not well known within the NU organization and the wider community in North Sumatra. This study uses a social history approach with the main source coming from the autobiography of Tuan Mukhtar Muda Nasution and other books he has written such as Sejarah Singkat Nabdlatul Ulama and supported by data from interviews with his friends and students. The results of this study indicate that Tuan Mukhtar was an educated man from the Mandailing tribe, who studied at the intellectual center of the early 20th-century Sunni tradition in the land of the Hijaz. In North Sumatra, Tuan Mukhtar is an icon of Islamic religious education, especially among pesantren (Islamic boarding schools). In Nahdlatul Ulama in North Sumatra, he was once the Mustasyar of PBNU and Syuriah of PWNU of North Sumatra. As for the field of da'wah, he is highly appreciated because he is widely known as a cleric who contributed to Islam in South Tapanuli. This study presents a broader elaboration of Tuan Mukhtar based on new and reliable sources.
\end{abstract}

Keywords: Nahdlatul Ulama; South Tapanuli; Tuan Mukhtar Muda Nasution.

\begin{abstract}
Abstrak
Artikel ini bertujuan untuk menganalisis kontribusi Tuan Mukbtar Muda Nasution terbadap organisasi Nabdlatul Ulama (NU), pendidikan, dan dakwah, khususnya di wilayah Tapanuli Selatan, Sumatra Utara. Di tengah pencapaian Tuan Mukhtar, para peneliti belum banyak meneliti tentang kontribusinya. Ia juga kurang dikenal baik dalam organisasi Nabdlatul Ulama dan masyarakat luas di Sumatera Utara. Studi ini menggunakan pendekatan sejarah sosial dengan sumber utama berasal dari autobiografi karya Tuan Mukhtar Muda Nasution dan buku-buku lain yang ditulisnya seperti Sejarah Singkat Nabdlatul Ulama, serta didukung oleh data wawancara dengan para sababat dan murid-muridnya. Hasil penelitian ini menunjukkan babwa Tuan Mukhtar adalab seorang terpelajar dari suku Mandailing, yang belajar di pusat intelektual dari tradisi Sunni awal abad ke-20 di tanah Hijaz. Di Sumatra Utara, Tuan Mukbtar merupakan ikon tokob pendidikan agama Islam, terkhusus di kalangan pesantren. Dalam Nabdlatul Ulama di Sumatera Utara, ia pernah menjabat sebagai Mustasyar PBNU dan Syuriah PWNU Sumatera Utara. Adapun dalam dunia dakwah, ia sangat dihargai sebab dikenal luas sebagai ulama yang berkontribusi terbadap Islam di Tapanuli Selatan. Studi ini menyajikan elaborasi yang lebih luas dari Tuan Mukhtar berdasarkan sumber baru dan tepercaya.
\end{abstract}

Kata Kunci: Nabdlatul Ulama; Tapanuli Selatan; Tuan Mukbtar Muda Nasution. 


\section{INTRODUCTION}

Nahdlatul Ulama (NU) in North Sumatra was initially established in South Tapanuli Regency, in Sidempuan City in 1947 AD, and was inaugurated at the same time as a congress held by scholars involving all Muslims in all parts of Tapanuli, on the 7th to the 9th February, 1947. Nahdlatul Ulama was founded to unite all levels of the Muslims in North Sumatra. Its efforts to protect it from the undermining of religious extremists, namely by continually upholding the teachings of ASWAJA, such as monotheism of Asya'ariyah Maturidiyah and following the 4 schools of thought adopted by NU itself. ${ }^{1}$

NU in North Sumatra was formed to respond to the North Sumatran ulamas to many religious beliefs that were not in line with the old understanding that had taken root in the community. Modernists emerged, such as Muhammadiyah, which developed its religious understanding to remote villages in North Sumatra. NU is the same as other Islamic organizations that want to develop rapidly anywhere. In order to maintain the existence of religious understanding amid society, the ulama worked hard to find the best way so that religious understanding remained upright. It is by establishing NU which was brought from Java as the basis and the beginning of the establishment of NU. ${ }^{2}$

Before the founding of Nahdlatul Ulama in North Sumatra, there were already several other Islamic organizations such as SI (Sarekat Islam), which was founded in 1905, Masyumi was founded in 1945, where Masyumi was synonymous with modernists, Muhammadiyah 1928 and Jam'iyatul Washliyah 1930 as an Islamic

1 Abrar M. Dawud Faza, "Merangkai Sejarah Nahdlatul Ulama Di Sumatera Utara," 2018, https://pwnusumut.or.id/2018/08/27/merangkai-sejarahnahdlatul-ulama-di-sumatera-utara/.

2 Abbas Pulungan, "Nahdlatul Ulama Di Luar Jawa: Perkembangan Di Tanah Mandailing," Journal of Contemporary Islam and Muslim Societies 2, no. 1 (June 2018): 91-127, https://doi.org/10.30821/jcims.v2i1.1747. organization that was born from the hands of native scholars of North Sumatra.

Ulama plays an important role in every process of Islamic development, both in education and da'wah in South Tapanuli. One of them is Tuan Mukhtar Muda Nasution, a cleric and leader from the Mandailing tribe, where he contributes through community organizations, education, and da'wah in his homeland, Sibuhuan Padang Lawas Regency, which was formerly part of South Tapanuli Regency. His contribution to the Nahdlatul Ulama organization was very large, it can be seen from the positions he had held from 1948 until he died in 2009. His first position in the Nahdlatul Ulama organization as chairman of the Jami'yah Council of Representatives of the Barumun District Branch from 1948 to 1952, until he became a delegate for the Province of North Sumatra to attend the PBNU congress and major conference.

'Tuan' is his nickname in the community and also as a special call to the ulama in South Tapanuli, as in Java, he is called 'Kyai'. Tuan Mukhtar is also engaged in religious education, such as teaching hadith, figh, monotheism and tool sciences (nahwu, nerves, and others). He was involved in educational activities from 1942 to 2009 , both as a teacher, lecturer and leader of several Islamic boarding schools. In the field of da'wah, he is preaching from village to village, assemblies taklim to majlis taklim, surau to surau, fostering ulama, religious teachers, fostering communities in minority areas, also participating in community religious activities in Padang Lawas. $^{3}$

In contrast to Abbas Pulungan's writings, which briefly mentions Tuan Mukhtar Muda Nasution as an important figure in the development of NU in Padang Lawas, this article further reviews the contribution of Tuan Mukhtar Muda Nasution in the development of

3 Adlan Ansor (Tuan Mukhtar's grandson), Interview, 15 October 2014. 
Nahdlatul Ulama, Education and Da'wah in South Tapanuli, especially in Padang Lawas Regency. This article uses a social history approach with the primary source coming from the autobiographical work of Tuan Mukhtar Muda Nasution and other books he wrote such as "A Brief History of Nahdlatul Ulama" and supported by data from interviews with students and colleagues. In writing this article, the researcher collected data related to the writing theme as needed from various sources by focusing on the life of Tuan Mukhtar Muda Nasution, a cleric from the Mandailing tribe in South Tapanuli.

\section{FROM SOUTH TAPANULI TO HIJAZ}

Tuan Muhktar Muda Nasution was born on January 9, 1921, in Wek II (Lorong Galanggang), Sibuhuan, Barumun District. His real name is Marahadan Nasution, the title Tuan Muhktar Muda given by his teachers while studying in Mecca. He is the son of Haji Muhammad Ludin Nasution bin Lobe Marusin bin Ja Manorsa bin Amal bin Ja Gading (Ja Gading came to Barumun District from Panyabungan-Mandailing). Tuan Mukhtar married Maimunah Hasibuan bint Haji Abdul Malik, at Sibuhuan Market, on November 29, $1941 .^{4}$

$\mathrm{He}$ is tall, white, the clothes he always wears when he leaves the house, he wears a sarong, a dark coat with a white shirt inside. Wear a turban wrapped around his head, wear leather sandals or shoes, when walking he sees the focus ahead, and when driving always at a moderate speed. His style and clothes never change even when he is invited to attend official events by state officials to the Presidential Palace. ${ }^{5}$

${ }^{4}$ Mukhtar Muda Nasution, Daftar Riwayat Hidup H. Mukbtar Muda Nasution-Sibubuan, (Sibuhuan, 8 Mei 2008), Catatan Kecil 7 Halaman.

5 Abrar, "Sejarah Hidup Tuan Mukhtar Muda Nasution,” https://pwnusumut.or.id/2019/07/19/sejarahhidup-Tuan-mukhtar-muda-nasution/, 2015.
Tuan Mukhtar is a cleric engaged in religious education, organization, social society, and politics. He was involved in educational activities from 1942 to 2009, both as a teacher, lecturer, and pesantren leader. Tuan Mukhtar started his early education at the SG school (Governor's school) in 1929 AD and completed primary education in 1934 . He was an intelligent and accomplished student who did not talk much — continuing to study at the 'Maktab Syariful Majlis' Sibuhuan at the Ibtidaiyah level, in 1931 AD - 1935 AD. During this education period, he was also called an unpretentious and solemn person; it was evident that he never complained about the situation, where there was a time of economic hardship and access to learning.

Not long after Tuan Mukhtar finished his education at Maktab Syariful Majelis, he continued his education at Tanjung Pura Langkat, Madrasah 'Maslurah' Tanjung Pura, class IV Ibtidaiyah in 1936 AD. He continued his education at the tsanawiyah level at Madrasah Aziziyah Tanjung Pura Langkat until class II year 1937 - 1938. In 1939-1941, he continued his education to the Hijaz (Makkah) land, to be precise at the Grand Mosque. He received education from leading scholars using the talaqqi/halaqah method, which is a learning method taught through meetings with teachers who teach in and around the Grand Mosque ${ }^{6}$.

\section{CONTRIBUTION TO NAHDLATUL ULAMA}

Nahdhatul Ulama was founded on January 31, 1926, in Surabaya, where the background of the establishment of this organization has a long and dynamic history, initiated by two significant ulama figures of their time Kyai Hasyim Asyari and Kyai Wahab

6 Ali Mutakin, "Kitab Kuning Dan Tradisi Intelektual Nahdlatul Ulama (NU) Dalam Penentuan Hukum (Menelisik Tradisi Riset Kitab Kuning)," Syariah Jurnal Hukum Dan Pemikiran 18, no. 2 (November 2018): 192-210, https://doi.org/10.18592/sy.v18i2.2270. 
Hasbullah7 ${ }^{7}$ The early history of its establishment stems from a thought-provoking discussion group formed by Kyai Wahab Hasbullah and his comrade-in-arms Kyai Mas Mansur. In the end, the Jam'iyah Nabdlatul Wathan organization or the 'Indonesian Awakening Association' was formed as a mission to improve madrasa education ${ }^{8}$.

On 21-27 August 1925, the 4th Al-Islam congress was held in Yogyakarta, which was to discuss the purification of Islamic teachings and not escape the discussion of the caliphate. The main purpose of the congress is an effort to maintain the religious traditions of Muslims in Indonesia which have been rooted from ancient times, such as still recognizing the tradition of the 4 schools of thought, namely, Hanafi, Maliki, Syafi'i and Hanbali. In this congress also intends to voice that the burial of the Prophet and his Companions is preserved without changing its shape or moving it.

From here, a committee was formed called the Hijaz Deliberation Committee, from this committee, the Nahdlatul Ulama was eventually formed, which was initiated by Kyai Hasyim Asyari. Nahdlatul Ulama's contribution to the state and nation cannot be doubted, especially at the moment of independence. Pancasila and the 1945 Constitution are accepted as the basis of the constitution in the state. A noble agreement of the nation's children, in which NU is considered successful in maintaining culture and contributing to the social field, so that it cannot be separated between NU's and Indonesia's?.

7 Ehwanudin, "Tokoh Proklamator Nahdlatul Ulama: Studi Historis Berdirinya Nahdlatul Ulama," Fikri: Jurnal Kajian Agama, Sosial Dan Budaya 1, no. 2 (2016): 44768.

8 Muhammad Rifai, K.H. Hasyim Asy'ari: Biografi Singkat (1871-1947) (Yogyakarta: Garasi, 2009).

9 Amin Farih, "Nahdlatul Ulama (NU) Dan Kontribusinya Dalam Memperjuangkan Kemerdekaan Dan Mempertahankan Negara Kesatuan Republik Indonesia (NKRI)," Walisongo: Jurnal Penelitian Sosial Keagamaan 24, no. 2 (December 2016): 251-84, https://doi.org/10.21580/ws.24.2.969.
At the time of the proclamation of independence, the contribution of Nahdlatul Ulama was more inclined to social and political transformation. The services of NU leaders and their citizens were very great for independence and resistance to colonialism during the struggle for independence and in the field of political parties in the 1955 elections. In the end, Nahdlatul Ulama took a stance to return to the 1926 khittah, the result of the 27th Congress in 1984 in Situbondo, East Java, left his sociopolitical role and opened a new page with a socioeconomic role. ${ }^{10}$

With the absence of Nahdlatul Ulama in the era of multi-party reform into the practical political arena, but still playing a strategic role for the continuity of the nation and state through the government. Politically, Nahdlatul Ulama residents are increasingly able to channel their political interests to the party they were born with, namely the National Awakening Party or commonly known as PKB. When the party has internal or external problems, Nahdlatul Ulama figures come down directly to give directions. So, the position of the ulama in the NU body is considered more than the politicians in their party.

In addition to its contribution to the nation and state, Nahdlatul Ulama also plays an active role in providing solutions to other countries, especially Muslim-majority countries. The establishment can see it of NU branches in several countries globally. Domestically, its branches are in various provinces, districts, subdistricts and villages. Each branch has its founding history and diverse dynamics since its inception. One of the dynamic branches of the Nahdlatul Ulama Regional Board is located in North Sumatra Province, which is still full of debate over the origin of its presence.

Not much is known about the history of the founding of Nahdlatul Ulama and the history

10 Mukhtar Muda Nasution, Sejarah Singkat Nahdhatul Ulama, t.t, t.p, 3. 
of its development in North Sumatra, even the PWNU administrators. In the body of Nahdlatul Ulama, there is anxiety because in the future, its early history and development will be lost to time because of the lack of historical codification and many of the characters who have died people who have experienced and seen the history ${ }^{11}$.

The main reason that moved the ulama to establish Nahdlatul Ulama in North Sumatra was religious reasons, such as the desire to strengthen the ASWAJA understanding, which was feared to be eroded by extreme understanding in the name of Islam. Another reason is to maintain religious traditions based on the 4 schools of jurisprudence and da'wah amar ma'ruf nabi munkarand tie a stronger brotherhood. Whereas in the social field, that is, to achieve a socially just life and a fair law for all levels of the nation's children, the hereafter is also achieved.

The beginning of the founding of Nahdlatul Ulama in Java has been heard in the ears of a great scholar of his time, namely Tuan Mustafa Husain Nasution, from the results of his conversations with scholars on the island of Java, fellow alumni of Makkah. He is the founder of the Mustafawiyah Mandailing Natal Islamic Boarding School. At that time he often traveled to the island of Java in the context of preaching and trading, because he was known as a merchant cleric. Prior to establishing NU in North Sumatra, North Sumatran clerics from the South Tapanuli section already had an Akbar Association called AII or Al-Ittihadiyah Islamiyah Indonesia, which Tuan Mustafa Husain himself led ${ }^{12}$.

In 1946 a meeting was held at the AII Tabliqh Akbar at Madrasah Mardiyah Islamiyah. At the deliberation, there was an agreement to form an organization that could protect Muslims, entrusted to Tuan Mustafa Husain to carry it out. The organization became a bulwark to ward off puritanism and efforts to gather the strength of

11 Abrar, "Sejarah Hidup Tuan Syekh Mukhtar Muda Nasution," 2015.

12 Abrar, "Sejarah Hidup Tuan Mukhtar Muda Nasution."
Muslims to repel invaders who came back after independence ${ }^{13}$. On 7-9 February 1947 a grand meeting was held which was attended by ASWAJA clerics who were blessed by Tuan Mustafa Husain. They came from all over Tapanuli such as Mandailing, Angkola, Sipirok, Padang Sidempuan, Padang Lawas, Natal, and Sibolga which are located in Madrasah Tarbiyah Islamiyah Kampung Bukit Sidempuan. In this association, the Nahdlatul Ulama organization was formed whose main management was on the island of Java ${ }^{14}$.

Over time, Nahdlatul Ulama began to spread in remote corners of South Tapanuli, one of the places where its development spread was in Padang Lawas Regency, one of the regencies that was formerly part of South Tapanuli Regency. NU is overgrowing by the help of the of the ulama who also studied in Makkah ${ }^{15}$. One of the scholars who significantly contributed to the development of Nahdlatul Ulama in Padang Lawas was Tuan Mukhtar. In particular, Tuan Mukhtar's contributions fall into four types, as follows: ${ }^{16}$

1. The contribution of education, as a figure who has a pesantren and teaches in it.

2. Spiritual contributions related to the position of the Lord, who often leads prayers and becomes the imam of prayers.

3. Social and organizational contributions related to the trust carried by a Tuan from the community as a leader or in other activities such as being the head of an organization, political figure, etc.

4. Administrative contributions related to positions as pesantren caregivers, dealing

13 Pulungan, "Nahdlatul Ulama Di Luar Jawa: Perkembangan Di Tanah Mandailing."

14 Pulungan.

15 Erawadi, "Peranan Ulama Tapanuli Bagian Selatan Dalam Pengembangan Lembaga Pendidikan Islam," https://www.academia.edu/28080436/Peranan_Ulama_Ta panuli_Bagian_Selatan_dalam_Pengembangan_Lembaga_P endidikan_Islam, n.d.

16 Rahmat Hasibuan (Pondok Pesantren Aek Hayuara-Sibuhuan Teacher), Interview, 15 October 2014. 
with administrative matters, leading, supervising, etc. ${ }^{17}$

Tuan Mukhtar influenced his thoughts in the history of Nahdlatul Ulama in Indonesia. Born into a pesantren family, he continued his education in Mecca and had a basic religious education before. After twenty years in the educational process, Tuan Mukhtar continued his service in his native South Tapanuli, particularly in Padang Lawas Regency. With qualified knowledge in the religious field, especially in Islamic law, he was able to lead him to become Rais Syariah of Nahdlatul Ulama for the North Sumatra Region and the central PBNU Mustasyar in his time. ${ }^{18}$

Besides having a significant contribution as the initiator of the founding of the North Sumatran Nahdlatul Ulama and one of the scholars who contributed to its development, there is another important contribution that has been played by Tuan Mukhtar, namely as the mouth of the religious spirit among the NU community in South Tapanuli. Tuan Mukhtar deserves to be called the mouth of the spirit of religion for NU residents because this cleric from the Padang Lawas-Sibuhuan Regency plays a major role in maintaining the traditions of Islamic boarding schools' traditions da'wah and government.

In these three issues, the people of South Tapanuli Nahdlatul Ulama are oriented to him, because he has succeeded in integrating the figh and zuhudan sides within himself. He also used the combination of fiqh and zubudan in educating his students. In addition to teaching his students with very strict physical knowledge, he also teaches spiritual knowledge. Tuan Mukhtar is also known as a scholar who contributed to the teaching of the Sahih-Bukhari book because he was a scholar who at his time was considered far deeper than others, moreover, he had a critical

\footnotetext{
${ }^{17}$ Ibid.

${ }^{18}$ Ibid.
}

view of the problems of pesantren, da'wah and government. ${ }^{19}$

The Nahdlatul Ulama organization is the largest religion-based organization in Indonesia, Tuan Mukhtar is one of the drivers in it. His dedication made him a person to be reckoned with in the Nahdlatul Ulama organization. Moreover, it can be seen from the positions and duties he has served while in it. ${ }^{20}$

1. Chairman of Jam'iyah N.U Majlis Deputy Branch of Barumun Sub-district from 1948 to 1952.

2. Chairman of Maa'rif N.U MWT Barumun District from 1953 to 1977.

3. Chairman of the N.U Educational Institution of South Tapanuli Regency from 1965 until he died in 2009.

4. Deputy Rois Syuriyah N.U South Tapanuli Regency from 1978 to 1984.

5. Chairman of Jam'iyah N.U North Sumatra Region from 19 May 1981 to 1985.

6. Rois Syuriyah N.U North Sumatra Region from 1986 to 2002.

7. Mustasyar PBNU Indonesia until he died in 2009.

8. Delegation of the Jam'iyah N.U Branch in Jakarta in 1950.

9. Delegates from the Jam'iyah N.U Branch of South Tapanuli Regency attended the N.U Mukhtamar to. 26 in Semarang, Central Java in 1979.

10. Envoys of the N.U Ulama Alim North Sumatra attended the N.U Alim Ulama National Conference in Kaliurung, Yogyakarta in 1981.

11. Envoys of L.P Ma'arif North Sumatra attended the National Conference of Ma'arif Educational Institutions in Ciputat Jakarta in 1983.

19 Jubeir Hasibuan (Tuan Mukhtar's Best Friend), Interview, 16 January 2015.

20 Mukhtar Muda Hasibuan, Daftar Riwayat Hidup H. Mukhtar Muda Nasution-Sibuhuan, (Sibuhuan, 8 Mei 2008). 
12. The delegation from Jam'iyah N.U for the North Sumatra Region attended the 27th N.U Congress in Situbondo, East Java, in December 1984.

13. Envoys of Jam'iyah N.U North Sumatra Region attended the N.U Conference at Kesugihan Cilacap, Central Java in 1987.

14. The delegation from Jam'iyah N.U for North Sumatra region attended the 28th N.U Mukhtamar in Yogyakarta in November 1989.

15. The delegation from Jam'iyah N.U for North Sumatra Region attended the N.U Grand Conference in Bandar Lampung, January 1992.

16. The delegation from Jam'iyah N.U for the North Sumatra Region attended the 29th N.U Congress in Cipasung, Tasik Malaya, West Java, in December 1994.

17. The delegation from Jam'iyah N.U for the North Sumatra Region attended the N.U Grand Conference in Ciawi, Bogor, West Java, on 15 Rajab 1416H/8 December 1995.

18. Envoys from Jam'iyah N.U North Sumatra attended the N.U Grand conference at the Qomarul Muda Islamic boarding school, Lombok, West Nusa Tenggara, from 16 to 20 Rajab 1418 H/ 17 to 21 September 1997 AD.

19. Principal teacher at Madrasah Tsanwiyah N.U Sibuhuan from 1947 to 1955, for 9 years.

20. Director of PGA N.U Sibuhuan from 1954 to 1980 , for 27 years.

21. Head of Madrasah Aliyah N.U Sibuhuan from 1955 to 1990.

22. Lecturer of the Faculty of Sharia UNUSU Padang Sidempuan from 1962 to $1966 .^{21}$

As a scholar with specific knowledge of hadith, fiqh, and qiro'at, Tuan Mukhtar is a "lawmaker" or reference to Padang Lawas

\footnotetext{
${ }^{21}$ Ibid.
}

scholars, generally people in South Tapanuli. ${ }^{22}$ Tuan Mukhtar is a figure who has a level of wisdom and piety. Wisdom is related to how much knowledge is gained, wisdom tends to how someone after getting that knowledge. Tuan Mukhtar has a fairly realistic view in his dialogue with the community. This means that it is quite contextual in translating Islamic values into social interaction. Thus, the community can become a religious society based on the religious understanding of Nahdlatul Ulama, and become an example for the next generation. At that time, many of his students and the public became politicians, scholars, and movers who were inseparable from their own influence. ${ }^{23}$

\section{CONTRIBUTION TO EDUCATION}

Entering the 15th century $\mathrm{H}$, the rise of Islam has become a discourse, besides long before, Muslims have experienced a long setback, especially in science and technology. In various parts of the community, they have begun to identify all the potential in it. Various creativity, innovation, and scientific experiments have been encouraged. Apart from experiencing various obstacles, Muslim civilization has begun to be inscribed as a form of its contribution to the world ${ }^{24}$.

In Indonesia, Muslims have begun to make great progress in improving the quality of the nation and state. Multi-dimensional emergencies can be responded to appropriately and still being exposed to the risks of the danger posed by changes due to political struggles between the nation's elite and the international community. The Indonesian Muslim community in a straightforward way, fair and good manner.

During these issues and changes, ethics and morals are starting to be felt as indispensable by the community. The framework of public

22 Sehat Muda (Tuan Mukhtar's Best Friend), Interview, 10 October 2014.

23 Ibid.

${ }^{24}$ Djamaluddin, Teologi Pendidikan (Jakarta: PT Raja Grafindo Persada, 2001), 100. 
activity and moral order can be used as a rule, not only for the state's existence but also for the nation's life. So moral rules are needed to direct everyone into a life of development and prosperity. ${ }^{25}$ In such a situation, to develop human beings in a country, it is necessary to have the best education and education system to become a foothold, as an effort to advance, and so that a nation or country does not lag in keeping up with the changing times.

All levels of the Indonesian nation agree to empower their human resources properly and as a whole. All nation's children also agreed that this would be achieved through education. It is just that until now the education in question has not had the option to show it as an institutional organization and has a quality implementation design. Therefore, it is hoped that there will be extraordinary consideration in the field of education and the courage not to use a framework that cannot provide answers to all the problems of education to this day ${ }^{26}$.

In order to attempt to trace a comprehensive and good school governance framework, it is important to consider current and future patterns of progress. Nahdlatul Ulama tries to give the expected reaction by proposing an effort to review the system implemented so far with these changes in conditions. Nahdlatul Ulama tries its best to adapt to social progress, so that every individual in society remains enthusiastic about everything that Nahdlatul Ulama, such as education develop.

Until now, the potential for education in the Nahdlatul Ulama environment is still a "dynamic potential" that must be realized. NU is imaged as an organization that is more inclined to manage the government, not as a Jam'iyyah Diniyyah or socio-religious community organization destined to empower the region through the development of da'wah instructive development (al-dakwah wa al-tarbiyah). Government issues do have their charm, but politics will be difficult to develop if the world of public education is still low.

${ }^{25}$ Ibid.

26 Diam Nafi' and Dkk., Praksis Pembelajaran Pesantren (Yogyakarta: PT L-kis Pelangi Aksara, 2007), 11.
Therefore, Nahdlatul Ulama needs to make instructive improvements that can answer the various difficulties of life from every point of view, because the future will be better seen from a good school system. Lack of improvement in education can lead to the collapse of social realities. Things like this can be circumstanced by activating changes, understanding interactions, and adjusting the dignity of NU through formal, non-formal and informal education channels ${ }^{27}$.

Thus, the need to expand networks with educational institutions outside NU, such as the private sector, government, and other global educational institutions, is a basic need. It is a stage or step to be able to react to every need of all levels of society globally to produce a great and quality society in the era of globalization. For Nahdlatul Ulama member, education is accepted as the main way to build reliable and strong human resources. It tends to be seen from education. Nahdlatul Ulama can participate in fostering the community's ability well, so that they have a soul, character, insight, wisdom, ability and a respected personality.

Tuan Mukhtar as a figure of Nahdlatul Ulama has a national role, one of the attractions of his homeland, Padang Lawas Regency, besides its geographical history is the existence of quite a lot of Islamic boarding schools. The existence of pesantren started from small surau, which were used to learn the Qur'an as the development of Islam in North Sumatra. This condition is similar to the history of Islamic boarding schools on the island of $\mathrm{Java}^{28}$. After the teacher settled and the times began to change, traditional institutions were formed that teach Islamic books. It is not limited to the holy Al-Quran but other supporting books.

27 Ali Rahim, "Nahdatul Ulama (Peranan Dan Sistem Pendidikannya)," Al-Hikmah: Journal For Religius Studies 14, no. 2 (2013): 158-67.

28 M Harahap and L M Siregar, "Dinamika Pondok Pesantren Dalam Membina Keberagamaan Santri Kabupaten Padang Lawas," JKIP: Jurnal Kajian Ilmu Pendidikan 1, no. 2 (2020): 26-37. 
Furthermore, in its historical context, pesantren does not only contain the meaning of Islamization or is Islamic, but becomes part of the local product, the original educational method of the Indonesian people during the HinduBuddhist period. ${ }^{29}$ The hermitage during the Hindu-Buddhist period became a traditional means of education and at that time, students from various regions wanted to study at the hermitage. Students are required to "mod" or stay temporarily at the hermitage for a certain period before finally completing their education. When Islam came, the close tradition was then adapted to be processed in such a way as to become a "Pesantren," which has Islamic characteristics but does not leave its previous characteristics. In other words, there has been an acculturation of the system in the transformation from "hermitage" or "dharma" to "Pesantren". 30

This theory comes from at least two existing realities, first seen from the personality relationship between educators and students which is practically equivalent to the character of the relationship between teachers and students. This character is a paternal relationship that existed as a principle bond in the Hindu-Buddhist era. Second, they have something in common between Islamic boarding schools and other religious-based institutions in the pre-Islamic period, namely traveling. Getting acquainted in searching for spiritual knowledge from one location to another.

Tuan Mukhtar's view thinks that teaching and education among NU citizens is an attempt to frame a country that is strong, physically and spiritually healthy and also intellectually minded, ready to develop thinking imagination, having information and abilities, applying a respectable personal attitude, encouraging mentality, love for the individual nation. Overall, education within the Nahdlatul Ulama body is centered on the

${ }^{29}$ Kusoi Lubis (Pesantren Ahmadul Jariyah Teacher, Pinang, Labuhan Batu Selatan District), Interview, 20 November 2014.

${ }^{30}$ Ibid. formation of Indonesian people who can do great things, are obedient, and give their dharma devotion to all levels of society. ${ }^{31}$

Tuan Mukhtar was the chairman of the Ma'arif Nahdlatul Ulama educational institution in Barumun District, the chairman of the NU Educational Institution of South Tapanuli Regency from 1965 until he died in 2009 and as a representative of the Ma'arif LP North Sumatra attended the National Conference of Ma'arif Educational Institutions in Ciputat Jakarta in 1983. The Ma'arif Institute is an educational foundation within the Nahdlatul Ulama body. The Ma'arif Education Foundation is an institution that is organized in a planned, conscious manner to foster all potential students so that they have a scientific spirit, are intelligent, have morals, are social, and have a good spiritual level. They can complete their obligations as caliphs, maintain solidarity and honesty in the community. They serve as pioneers in the development of Abl Sunnah Wal Jama'ah understanding. ${ }^{32}$

In Tuan Mukhtar's view, managing a private educational institution is not easy and can be classified as a very tough job. The administrators of these educational institutions must teach proper dedication so that the community can face difficulties developing and maintaining it. It is described in the statement above that the challenges in implementing education are not easy things. It is clearly seen that Indonesia is facing problems in developing human resources and almost all nations in the world. It is no secret that education in Indonesia lags behind other Southeast Asian countries.

The cause of this problem is that the community still ignores the education sector. It has resulted in Indonesia only having a small proportion of the nation's children who have higher education and high morals. This factor may be the cause of the multidimensional crisis.

31 Jubeir Hasibuan (Tuan Mukhtar's Best Friend), Interview, 16 January 2015.

32 Ibid. 
Nahdlatul Ulama has an educational institution, namely a pesantren, which has always developed in the Islamic community of the archipelago. The existence of Nahdlatul Ulama until now has always been closely related to pesantren ${ }^{33}$.

Pesantren is a source of strength that was established to give birth to cadres of ulama, from here the Jami'yyah Nahdlatul Ulama was formed. Pesantren education is a dimension that is always in principle, which has always been referred to as a symbol of boredom and stagnation. In reality, the dynamic development of pesantren is dynamic, can change at any time, has strong potential in playing a role in directing and making the desired change movement, able to adapt to the times.

The progress of pesantren is increasing rapidly in various parts of the country, where so far pesantren is seen as an educational institution that is powerless and unable to educate, but the reality is quite the opposite. One might say that the pesantren living in the interior have now become a symbol and model for a different school, embracing strict learning and discipline. Pesantren have the option to follow the progress of teaching according to the circumstances. In an effort to reduce the problems of the pesantren education system, according to Tuan Mukhtar's point of view, it takes courage to rebuild in the sense of building or developing pesantren based on its potential. lead to the loss of the identity of the pesantren.

The redevelopment does not require changing the orientation or reducing the orientation and idealism of Islamic boarding schools known as "tafaqquh fidin" institutions, nor does it have to change existing values such as brotherhood, sincerity, simplicity, optimism and independence. Tuan Mukhtar is one of the Nahdlatul Ulama figures at the national level who has contributed a lot to instructive issues, be it Islamic boarding schools among Nahdlatul Ulama and other public schools. He argues that pesantren is an

33 Arief Subhan, Lembaga Pendidikan Islam Indonesia Abad Ke 20 (Jakarta: Prenada Media Group, 2012), 177. educational institution that cannot be separated from society, especially rural networks.

Pesantren is an institution that teaches religion so that it cannot be separated from the life of every individual Muslim, especially Muslim communities in rural areas. Islamic boarding schools develop and create from region to region by making pesantren part of the community from an innovative perspective. ${ }^{34}$ Pesantren is a religious institution closely related to the community, especially for people who live in rural areas. Pesantren is an institution that develops in society which is always a part of society with transformative purposes. Pesantren is a separate institution, which stipulates that teachers, students, and their management bodies live together in the pesantren environment, which upholds Islamic values and customs different from other communities living outside the pesantren environment.

Today in general, Islamic boarding schools have experienced changes along with the times. The position of the teacher is no longer the only source of knowledge, along with the increasing number of sources of new knowledge, and the development of technology, information, and communication ${ }^{35}$. Since independence, Islamic boarding schools have become a characteristic of Indonesia, where the two are inseparable. During the colonial period, pesantren were always present in fighting for nationalism (khubbulwathan) of Muslims to liberate Indonesia from the hands of the invaders. Pesantren is an institution that teaches religion and instills a sense of love for the homeland and respect for fellow nation's children.

Islamic boarding schools teach their students not only to think exclusively, but also to teach the substance of religious values. In the social world, Tuan Mukhtar stated that pesantren has always been an institution with a major role as

\footnotetext{
${ }^{34}$ Ibid.

35 A Rofiq, Pemberdayaan Pesantren Menuju Kemandirian Dan Profesionalisme Santri Dengan Metode Daurah
} Kebudayaan (Yogyakarta: Pustaka Pesantren, 2005), 6. 
a social foundation based on religious values. The source of the closeness of the pesantren to the community is built on these religious values. It forms the closeness between the pesantren and the community psychologically and ideologically. ${ }^{36}$

Islamic boarding schools were born from the psychological depths of rural religious communities. It makes pesantren referred to as psychological bonds. Because Islamic boarding schools are also a bulwark of resistance from group beliefs whose principle is that only religion is considered ideological in the state and nation. Islamic boarding schools emerge from the recognition of community values and are expressed in educational institutions based on religious values, the strength of this community base is the driving force for the existence of these institutions.

By looking at the various identification efforts, it is clear that research on pesantren has been carried out quite seriously. This effort deserves appreciation, especially given the historical significance of the pesantren and its contemporary status as a major educational place for Muslims. Next, a summary of pesantren's role and will continue to play. ${ }^{37}$ The occurrence of an emotional relationship with the community is because pesantren was born from the community itself, where people have wanted a religious social life, close to religious values. Islamic boarding schools also have an ideological relationship with the community because they become a bulwark against the community's beliefs, namely the existence of the religion they follow. It can be concluded that Islamic boarding schools were born from society's noble ideals, which were realized through educational institutions in which religious values were instilled.

It can be seen from the identification that studies related to the world of Islamic boarding schools have been carried out seriously. In terms

\footnotetext{
${ }^{36}$ Ibid., 14.

${ }^{37}$ Ibid.
}

of the position of the pesantren, this effort should be appreciated because the history that has been written is sufficient to become knowledge to make pesantren as an Islamic reference. Moreover, it can be read about how the history of its role in society so far.

It is not only the property and obligation of pesantren in the context of community social development, but it is also a shared responsibility between the government and the community. However, the presence of pesantren does not directly influence the formulation of regulations, so its role is classified as participation. In this situation, the pesantren has the power to mobilize society as a whole through its teachers and students. However, the existence of ulama as social and religious elites has a vital position and role in the social structure of Indonesian society. Pesantren in general are the life force of the community in carrying out religious values according to the needs of the citizens. Pesantren also help religious communities develop a sense of national pride. ${ }^{38}$

Tuan Mukhtar is one of the leaders of the Nahdlatul Ulama organization, North Sumatra. One of the driving forces behind the pesantren movement is the spiritual leaders of the community and government. As a scholar, heir to the prophets (waratsatul anbiya), who inherits the knowledge of the prophets, knowledge must appear in people's lives and be a positive example. Ulama becomes a role model for society, where people imitate and follow their words. People also imitite their actions and behavior are always used as a reference by the community.

Tuan Mukhtar is seen as a helpful figure and a giver of blessings, which in the end, in the pesantren community, every action of the santri is very dependent on his blessing and movements. Teachers and students alike try to avoid doing things that are not good in front of them. Tuan Mukhtar's relationship with the community is based on adherence to religion and in the end this 
is what makes him highly respected by the community. His actions are accompanied by charisma, which adds to the emotional intensity of the relationship between the two. Because he has become a resource for the community in solving problems that are spiritual and cover a wider part of life, the community also relies on him to be a leader and representative in national affairs.

Tuan Mukhtar is a pesantren leader and a spiritual figure at the Padang Lawas Regency government level, where the community puts full trust in him in religious and state affairs. It is closely related to socio-cultural factors that will develop a sense of nationalism and religion in South Tapanuli, especially among Islamic boarding schools. ${ }^{39}$ The interaction between pesantren and the community is a collaborative effort that aims to promote an effective two-way information channel with a culture of mutual understanding between pesantren, pesantren administrators, and the general public. Tuan Mukhtar's efforts to develop interactions between pesantren and the community are similar to pesantren empowering the community, where the pesantren under his care provide religious knowledge and insight and awareness in dealing with all problems. ${ }^{40}$

In connection with several Islamic boarding schools he leads, such as the AlMukhtariyah and Al-Mukhlisin Islamic Boarding Schools and several other Islamic boarding schools, they are very beneficial for the growth of religious studies in the Padang Lawas area, generally in South Tapanuli, where the relationship between the pesantren and the community is very close. ${ }^{41}$ The relationship between pesantren and the community is established to increase public awareness to care about the needs and educational activities in Islamic boarding schools and encourage interest

39 Jubeir Hasibuan (Tuan Mukhtar's Best Friend), Interview, 16 January 2015

${ }^{40}$ Ibid.

${ }^{41}$ Ibid. and cooperation between pesantren and the community in order to improve and develop pesantren $^{42}$.

Tuan Mukhtar's efforts in strengthening the relationship between the pesantren and the community are numerous. In community empowerment, it provides knowledge about religion. However, the pesantren under its leadership also provides understanding and awareness in addressing all religious and national issues, mobilizing the community always to participate and be a pioneer in solving problems related to social problems. ${ }^{43}$ In education, Tuan Mukhtar has the same commitment and determination as Nahdlatul Ulama's educational commitment, seen from his position as one of the leaders of the NU organization. The direction, orientation, and identity of education promoted by Tuan Mukhtar are guided by various principles in the administration of education, including: ${ }^{44}$

1. Committed to the religious worldview of Ahl Sunnah Wal Jamaah.

a. Strong desire to establish their own educational institution, both in orientation, initiative, and management style.

b. Can improve educational institutions by utilizing the full potential of the community.

c. Establishing mabadi 'khaira ummah as the foundation of educational management, which reflects the ideals of shidiq (truth), al-aminah (trust), al-'adilah (justice), al-ta'dwun (cooperation), and al-istiqamah (consistency towards truth).

${ }^{42}$ Rustalena dkk, "Biography of the Syekh $\mathrm{H}$. Mukhtar Muda Nasution As a Figure in Islamic Education in the Sub-District Barumun District Padang Lawas 19212009" 6 (2019): 1-10.

43 Ahmad Fauzan Nasution (Head of Pesantren Al-Mukhlisin-Sibuhuan, Padang Lawas District), Interview, 8 October 2014.

${ }^{44}$ Jubeir Hasibuan (Tuan Mukhtar's Best Friend), Interview, 16 January 2015. 
d. Willing to make many efforts to maintain the value of work and charity and make worship into achievement

2. Under his supervision, the educational policy of NU-based Islamic boarding schools is based on the idea that education is an effort to develop individual humans into real humans in the sense of having high social sensitivity and being able to develop the function of the caliphate on earth, including the creation of manufacturing tools (intellectual mechanics).

3. Maintain a balance between the desire to move and the need to self-regulate. These two factors contribute to the characteristics of proper education in NU's education, namely the existence of deep historical and traditional roots and the ability to foster a sense of involvement in the education system as a whole. ${ }^{45}$

\section{CONTRIBUTION TO ISLAMIC DA'WAH}

Of course, it cannot be denied that Islamic da'wah and education play an essential role in Islamization of the archipelago. Despite the many debates and discussions about the arrival of Islam in the archipelago, the development of Islam can be seen from the success and process of da'wah and education carried out by Muslims themselves after Islam entered the archipelago ${ }^{46}$.

It is in line with one of the conference results on the arrival of Islam to Indonesia, which was held in Medan in 1963, which stated that once Islam entered Indonesia, the Indonesian people actively participated in the process of Islamization. These facts are not challenging to understand historically because Islamic da'wah and education played an important role in the development of Islam and the spread of reform

45 Hatimbulan Daulay (Tuan Mukhtar's Best Friend), Interview, 9 October 2014.

46 A Hasjmy, Sejarah Masuk Dan Berkembangnya Islam Di Indonesia, 2nd ed. (Bandung: PT. Al-Ma'arif, 1989), 7. ideas even before the Europeans, especially the Dutch who came with their colonialism. ${ }^{47}$

Both in society and Islamic educational institutions and da'wah both go hand in hand to spread Islam. At that time, Islamic education and da'wah took the form of halaqah, or group teaching in mosques, institutions, or Islamic boarding schools. The importance of da'wah in the process of Islamization and Islamic renewal cannot be separated from the creativity of the ulama. They played an important role in the process of Islamization and the development of Islam." They are scattered throughout the archipelago, as is the case with the process of Islamization and the development of Islam in Padang Lawas, South Tapanuli.

With his various services, Tuan Mukhtar is one of the major figures who contributed to the Islamization of behavior and the development of Islam in South Tapanuli, using Islamic da'wah and education. Many statements reveal that he is one of the scholars who cares about the development of Islam and the struggle to establish Islam in South Tapanuli. ${ }^{48}$

Tuan Mukhtar's contribution as a cleric in the growth of Islam in South Tapanuli and his efforts in the struggle against conceptions that are contrary to Islamic ideals cannot be denied. Many things need to be revealed and understood about his life journey, especially the efforts to develop Islamic teachings in South Tapanuli. ${ }^{49}$

$\mathrm{He}$ is described as a person who is consistent in all actions. His enthusiasm is extraordinary, full of confidence, discipline, authority, and a desire to share knowledge. His personal wealth is reflected in his complexion, which is always bright and cheerful. Even though he spent time teaching in various places, both in his pesantren and in his upbringing assemblies, there was no sign of fatigue on his face, and

\section{${ }^{47}$ Ibid.}

48 Kusoi Lubis (Pesantren Ahmadul Jariyah Teacher, Pinang, Labuhan Batu Selatan District), Interview, 20 November 2014.

${ }^{49}$ Ibid. 
nothing could match his discipline and determination..$^{50}$

His activities show that he is a person who has noble principles of manner. His students regard him as a teacher who imparts knowledge to them and directs them to have noble manners in learning. Tuan Mukhtar is a consistent Islamic preacher preaching against gambling, liquor, and adultery. His da'wah has a quality that is inspired by the mastery of knowledge by his teacher, and his da'wah movement brings a rejuvenating dimension to society.

Tuan Mukhtar built the "Bina Ulama" taklim assembly, which became a place for Padang Lawas clerics to study the yellow book and Da'wah Islamiyah and other Islamic learning facilities. The Bina Ulama taklim assembly has emerged as the main means of transforming and internalizing Islamic teachings in society, especially among its students. His taklim assembly has become a powerful propaganda tool. One of the most interesting aspects of the Majelis taklim educational institution "Bina Ulama" founded is how his students receive lessons and character, but are also forged as militant da'wah soldiers in broadcasting religious teachings. ${ }^{51}$

Tuan Mukhtar's enthusiasm and motivation in fighting ignorance and injustice cannot be separated from his understanding of Islam. It is not easy to find and map out his position and role as ulama, da'i, and fighters, all of whom are his members. In the literature that discusses him, it is known that he uses religious teachings as a tool to preach things that are contrary to Islam. Misunderstanding and hostility towards religious ties under any pretext or name, according to Tuan Mukhtar, is an injustice that must be removed from South Tapanuli. Tuan Mukhtar's Islamic preaching and development activities in the South Tapanuli area are very similar to what he does in all parts of Tapanuli.

\section{${ }^{50}$ Ibid.}

51 Togu Hasan Lubis (Guru Godang Madarasah Ibtidaiyah Al-Ma'arif NU, Hutarimbaru, Padang Lawas District). Interview, 20 October 2014.
He has been advocating the practice of Islam in South Tapanuli, Padang Lawas, for many years, with great success. It is known that he never complained in developing Islamic da'wah to the community, until he earned the community's respect. He developed the Islamic da'wah is also inseparable from the services of his comrades in arms at that time. ${ }^{52}$ Tuan Mukhtar tried to get the community's sympathy by influencing community and traditional leaders. He looked more deeply into local customs, conveyed religious information, provided useful instructions and guidance to the community to increase the area of struggle and da'wah. He has a good understanding of how to behave and adapt to local norms, and as a result, he becomes a wellliked and respected individual.

Tuan Mukhtar is not the only cleric who first made a significant contribution to da'wah in South Tapanuli, especially Padang Lawas, but his contribution to the continued development of Islam cannot be ignored. ${ }^{53}$ The taklim assembly is used as a means of training formidable da'wah soldiers, as well as a place for discussion. Another purpose of the taklim assembly is to serve as a forum for friendship for all levels of society. It is both from the ulama, students, and society in general. Thus, the range of knowledge taught is more significant to the general public, especially Islamic boarding schools in South Tapanuli. ${ }^{54}$

Tuan Mukhtar's success in forging his students to become militant da'wah soldiers became an important factor in how he eventually became a commando in preaching amar ma'ruf nabi munkar. ${ }^{55}$ Tuan Mukhtar for the people is a very respected figure in his time. In him, various roles have been formed, both as fighters, preachers, educators in the community. People see that all their actions are a picture of religion. Religion he made as the spearhead in concocting

52 Ahmad Fauzan Nasution (Head of Pesantren Al-Mukhlisin-Sibuhuan, Padang Lawas District), Interview, 8 October 2014.

53 Ibid.

54 Hatimbulan Daulay (Tuan Mukhtar's Best Friend), Interview, 9 October 2014.

${ }^{5}$ Ibid. 
his da'wah well, either through education, organization or politics and he also adapted to the typology of society. The core purpose of his da'wah is for people to follow the rules of religion, because religion is a rule to achieve a good society. Religion is also a means to achieve the goals that can be carried out by God's will, such as good social relations or civil society. ${ }^{56}$

Tuan Mukhtar's da'wah and all aspects related to religion are no different from other South Tapanuli. He believes that preaching is something that must be done for the sake of creating a religion that is rabmatan lil 'alamin. His da'wah activities in the South Tapanuli area began when he returned to study Islam in Mecca. The teachers advised and mandated to carry out da'wah tasks and develop Islamic teachings in the regions. He is considered successful as a preacher in South Tapanuli-Padang Lawas with satisfying results. ${ }^{57}$

Tuan Mukhtar is known as an open person, by promoting discussion. He is known as a person who does not impose his opinion on people who disagree, this is considered proof of his character. In expanding the da'wah in South Tapanuli, Tuan Mukhtar treated the community very humanely. ${ }^{58}$ He built good relations with the adat, pious scholars, clever and not antipathetic to the various traditions that exist in the community. Although Tuan Mukhtar is not the only cleric who first made a significant contribution to da'wah in South Tapanuli, it is just that Tuan Mukhtar is the most prominent among all the existing figures, both in education, da'wah, and also to NU's.

Tuan Mukhtar conveyed his oral da'wah to the public by using the yellow book to reference his preaching. The books become the handle of Abl Sunnab wal Jama'ah and the NU organization. ${ }^{59} \mathrm{He}$ mastered the way of da'wah and good teaching, for example, he distinguished

\footnotetext{
${ }^{56}$ Ibid.

${ }^{57}$ Ibid.

58 Jubeir Hasibuan (Tuan Mukhtar's Best Friend), Interview, 16 January 2015.

59 Ibid.
}

the clergy, students, teachers, and ordinary people. Among the scholars, he taught and preached according to their needs, using books of higher quality, such as the science of monotheism, he used the book al-Hud Hudi and similar books. In ordinary people, he uses the book kifayatul awwam, and among students uses the book al-Husunul Hamidiyah and its equivalent.

The da'wah method he used during his preaching was showing the reference book he delivered, and mentioning the page was one of Tuan Mukhtar's unique features. He is a scholar who is consistent in referring to the teachings he conveys from classical books that have been the grip of Muslims for a long time. ${ }^{60}$ In his view, da'wah must refer to good opinions and those that have become the reference for most Muslims. ${ }^{61}$

Tuan Mukhtar's contribution as a cleric in the South Tapanuli can impact the rapid development through da'wah and education. The community highly appreciates his contribution in da'wah. All the results of his contributions are still maintained by the da'wah soldiers he formed, who were prepared for the people when he was gone. Tuan Mukhtar and Da'wah Islamiyah are like 'the only soul and body', which cannot be separated, it was proven until he left the world for good. ${ }^{62}$

In South Tapanuli, he is known as one of the founders of religious education, apart from his teachers. He is believed to be in charge of the learning curriculum in several Islamic boarding schools and schools under the guidance of NU in South Tapanuli because he is considered a competent scholar in the management of pesantren. Concerning Nahdlatul Ulama, he believes that he can use the organization as a field for da'wah, besides NU being the only one that can be a forum for defending the teachings of its predecessors. From the Nahdlatul Ulama
${ }^{60}$ Ibid.
${ }^{61}$ Ibid.
${ }^{62}$ Ibid. 
organization, he moved to convey the religious knowledge he mastered. ${ }^{63}$

\section{CONCLUSION}

Tuan Mukhtar Muda Nasution, based on the above study, is someone who has contributed significantly to the development of Nahdlatul Ulama both on a local and national scale. Fighters for education and da'wah in South Tapanuli, both among the educated and the wider community. His contribution within NU itself can be seen from his position in the organization, from 1948 to 2009, when he died. Tuan Mukhtar is a respected figure within the NU organization in South Tapanuli, generally in North Sumatra. He is the successor to his predecessor Tuan Mustafa Husain Nasution as the early founder of NU in North Sumatra.

In the field of education, he is considered to have contributed, especially in the field of religion, as an alumnus of the Hijaz land; he is indebted to his homeland to educate the people and fill them spiritually so that they are always close to God. As an effort so that Islam is embedded in the community. Tuan Mukhtar deserves to be called the father of education in his homeland, because the community trusts him to be a model for education from the basic level to the highest level.

It can be seen from his leadership in several Islamic boarding schools and religious schools, such as being the chairman of the Ma'arif NU educational institution in Barumun District, the chairman of the NU Educational Institution in South Tapanuli Regency from 1965 until he died in 2009 and the envoy of the Ma'arif Prison in North Sumatra. Attended the National Conference of Ma'arif Educational Institutions in Ciputat Jakarta in 1983, the leadership of the Aek Haruaya Sibuhuan Islamic Boarding School, the Al-Mukhtariyah Islamic Boarding School Sibuhuan and the Al-Mukhlisin Islamic Boarding

\footnotetext{
63 Ibid.
}

School Sibuhuan, and several other schools in the Padang Lawas Regency. ${ }^{64}$

His contribution in the field of da'wah is certainly not in doubt, his name is very famous in the community until now, because he struggles to preach from village to village, mosque to mosque, surau to surau and also within the local government he is considered one of the active roles in supply the spirit within. Tuan Mukhtar cadres prospective ulama to be his mouthpiece in the wider community, to remote villages. Tuan Mukhtar founded the Bina Ulama taklim assembly, which functioned as a place for Islamic learning facilities for Padang Lawas clerics, in learning the yellow book and Da'wah Islamiyah. The taklim assembly has become the main means of transforming and internalizing Islamic teachings to the community, especially to its students.

The taklim assembly became a tough training tool for all its da'wah cadres. It is used as a means of education, not only to make the cadres understand religion, but more than that, to become loyal cadres with the world of da'wah. Thus, the range of knowledge he teaches is greater even among public schools, especially Islamic boarding schools in South Tapanuli. ${ }^{65}$

\section{REFERENCES}

Abrar. "Sejarah Hidup Tuan Mukhtar Muda Nasution."

https://pwnusumut.or.id/2019/07/19/sejar ah-hidup-Tuan-mukhtar-muda-nasution/, 2015.

. "Sejarah Hidup Tuan Syekh Mukhtar Muda Nasution," 2015.

Djamaluddin. Teologi Pendidikan. Jakarta: PT Raja Grafindo Persada, 2001.

Ehwanudin. "Tokoh Proklamator Nahdlatul Ulama: Studi Historis Berdirinya Nahdlatul

${ }^{64}$ Mukhtar Muda Hasibuan, Daftar Riwayat Hidup H. Mukhtar Muda Nasution-Sibubuan, (Sibuhuan, 8 Mei 2008).

65 Hatimbulan Daulay (Tuan Mukhtar's Best Friend), Interview, 9 October 2014. 
Ulama." Fikri: Jurnal Kajian Agama, Sosial Dan Budaya 1, no. 2 (2016): 447-68.

Erawadi. "Peranan Ulama Tapanuli Bagian Selatan Dalam Pengembangan Lembaga Pendidikan Islam." https://www.academia.edu/28080436/Pera nan_Ulama_Tapanuli_Bagian_Selatan_dala m_Pengembangan_Lembaga_Pendidikan_Is lam, n.d.

Farih, Amin. "Nahdlatul Ulama (NU) Dan Kontribusinya Dalam Memperjuangkan Kemerdekaan Dan Mempertahankan Negara Kesatuan Republik Indonesia (NKRI)." Walisongo: Jurnal Penelitian Sosial Keagamaan 24, no. 2 (December 2016): 25184. https://doi.org/10.21580/ws.24.2.969.

Faza, Abrar M. Dawud. "Merangkai Sejarah Nahdlatul Ulama Di Sumatera Utara," 2018. https://pwnusumut.or.id/2018/08/27/mer angkai-sejarah-nahdlatul-ulama-di-sumaterautara/.

Harahap, M, and L M Siregar. "Dinamika Pondok Pesantren Dalam Membina Keberagamaan Santri Kabupaten Padang Lawas." JKIP: Jurnal Kajian Ilmu Pendidikan 1, no. 2 (2020): 26-37.

Hasjmy, A. Sejarah Masuk Dan Berkembangnya Islam Di Indonesia. 2nd ed. Bandung: PT. AlMa'arif, 1989.

Mutakin, Ali. "Kitab Kuning Dan Tradisi Intelektual Nahdlatul Ulama (NU) Dalam Penentuan Hukum (Menelisik Tradisi Riset Kitab Kuning)." Syariab Jurnal Hukum Dan Pemikiran 18, no. 2 (November 2018): 192210.

https://doi.org/10.18592/sy.v18i2.2270.

Nafi', Diam, and Dkk. Praksis Pembelajaran Pesantren. Yogyakarta: PT L-kis Pelangi Aksara, 2007.

Pulungan, Abbas. "Nahdlatul Ulama Di Luar Jawa: Perkembangan Di Tanah Mandailing." Journal of Contemporary Islam and Muslim Societies 2, no. 1 (June 2018): 91-127. https://doi.org/10.30821/jcims.v2i1.1747.

Rahim, Ali. "Nahdatul Ulama (Peranan Dan
Sistem Pendidikannya)." Al-Hikmah: Journal For Religius Studies 14, no. 2 (2013): 158-67.

Rifai, Muhammad. K.H. Hasyim Asy'ari: Biografi Singkat (1871-1947). Yogyakarta: Garasi, 2009.

Rofiq, A. Pemberdayaan Pesantren Menuju Kemandirian Dan Profesionalisme Santri Dengan Metode Daurah Kebudayaan. Yogyakarta: Pustaka Pesantren, 2005.

Rustalena dkk. "Biography of the Syekh H . Mukhtar Muda Nasution As a Figure in Islamic Education in the Sub-District Barumun District Padang Lawas 1921-2009" 6 (2019): 1-10.

Subhan, Arief. Lembaga Pendidikan Islam Indonesia Abad Ke 20. Jakarta: Prenada Media Group, 2012.

\section{Wawancara}

Ansor, Adlan. (Tuan Mukhtar's grandson), Interview, 15 October 2014.

Daulay, Hatimbulan. (Tuan Mukhtar's Best Friend), Interview, 9 October 2014.

Hasibuan, Jubeir (Tuan Mukhtar's Best Friend), Interview, 16 January 2015.

Hasibuan, Rahmat. (Pondok Pesantren Aek Hayuara-Sibuhuan Teacher), Interview, 15 October 2014.

Lubis, Kusoi. (Pesantren Ahmadul Jariyah Teacher, Pinang, Labuhan Batu Selatan District), Interview, 20 November 2014.

Lubis, Togu Hasan. (Guru Godang Madarasah Ibtidaiyah Al-Ma'arif NU, Hutarimbaru, Padang Lawas District). Interview, 20 October 2014.

Muda, Sehat. (Tuan Mukhtar's Best Friend), Interview, 10 October 2014.

Nasution, Ahmad Fauzan. (Head of Pesantren Al-Mukhlisin-Sibuhuan, Padang Lawas District), Interview, 8 October 2014. 